УДК 336.22

DOI https://doi.org/10.32837/pyuv.v0i3(32).603

С. М. Сличок

orcid.org/0000-0001-7040-6223

кандидат юридичних наук,

асистент кафедри фінансового права

Наиіонального юридичного університету імені Ярослава Мудрого

\title{
ПРЕЗУМПЦІЯ ПРАВОМІРНОСТІ РІШЕНЬ ПЛАТНИКА ПОДАТКІВ У ПРАКТИЦІ АДМІНІСТРАТИВНИХ СУДІВ
}

Презумпція правомірності рішень платника податків - один з основних принципів податкового законодавства. Непоодинокі випадки, коли неоднозначність розуміння підходів до правозастосування зумовлює виникнення суперечностей між платником податків і контролюючим органом. У такій ситуації з об'єктивних причин владний суб'єкт (контролюючий орган) має правові переваги перед платником податків. Для мінімізації переваг адміністративного становища контролюючого органу та забезпечення інтересів платника податків було сконструйовано на нормативному рівні презумпцію правомірності рішень платника податків. У подальшому концепція презумпції правомірності рішень платника податків розвивалася в межах судової практики.

Перед безпосереднім розглядом відповідної проблематики потрібно проаналізувати загальнотеоретичні визначення поняття «презумпція» . Поняття «презумпція» походить від латинського слова "praesumptio" та означає припущення, яке основується на ймовірності, або нормативно закріплене припущення щодо конкретного факту, наявність якого розглядається як істинне та не зумовлює необхідності його доказування [7, с. 869]; або припущення, що розглядається як достовірне доти, доки не буде встановлено протилежне [2, с. 535-536].

Оскільки презумпції прийнято класифікувати на логічні та правові, у рамках даного дослідження ми будемо аналізувати саме правові презумпції, які не завжди відображають об’єктивні закономірності фактичної дійсності. На думку В.К. Бабаєва, презумпції у праві являють собою різновид презумпцій об’єктивованого характеру, які мають характер узагальнень індуктивно зумовленої природи [1, с. 13]. Ю.М. Грошевий визначає правові презумпції як спеціальне правило, відповідно до якого доказовість певного факту зумовлюється доказовістю іншого факту. Або ж припущення про наявність або відсутність конкретного факту розглядається як дійсне до моменту його спростування [4, с. 265]. А.Й. Іванський зазначає, що презумпції - це припущення, які визначають наявність або відсутність певних юридичних фактів, що грунтуються на зв'язку між тими фактами, щодо яких робиться припущення, і тими фактами, що існують, і це набуває підтвердження в реаліях об’єктивної дійсності [5, с. 223].

Ю.А. Ведерніков i А.В. Папірна визначають презумпції як нормативно закріплені припущення щодо явища або юридичного стану [3, с. 133-134]. А.М. Слюсар розглядає презумпцію як зумовлене логікою попереднього досвіду припущення стосовно наявності або відсутності конкретних фактів, що засновується на логічних зв'язках між очікуваними та наявними фактами [16]. О.Є Кухарєв характеризує правову природу презумпцій у праві та визначає їх як інструмент визнання певного факту як достовірного, доки не буде встановлено протилежне. Як зауважує автор, правові презумпції в рамках правозастосовної практики можуть бути спростовані. Основа презумпції - припущення, яке основується на природних закономірностях речей та процесів. Відповідне припущення розглядається як таке, що є потенційно правильним, доки його не спростовано [6]. Фактично, правова презумпція $\epsilon$ специфічним техніко-юридичним прийомом, що дозволяє говорити про її ймовірнісний, а не обов'язково дійсний характер.

Потрібно зауважити, що в аспекті логічних (фактичних) презумпцій, можливо, припущення має ймовірнісну природу й основується на закономірностях об’єктивної дійсності. Що ж стосується правових презумпцій, то їхнє головне завдання зазвичай полягає в забезпеченні прав та інтересів конкретних учасників правовідносин, забезпеченні правової визначеності, гарантуванні певного становища. Правові презумпції не обов'язково повинні відображати фактично наявний стан справ. У результаті проведеного аналізу наукових підходів до визначення правових презумпцій можемо запропонувати таке визначення даного поняття: презумпція - це техніко-юридичний прийом, за посередництвом якого встановлюється припущення про наявність або ж відсутність конкретного явища, що в подальшому може бути спростовано в рамках правозастосовної практики.

У національній системі податкового законодавства презумпція правомірності рішень платника податків вперше формалізована в рамках 
Закону України «Про порядок погашення зобов'язань платників податків перед бюджетами та державними цільовими фондами». Важливо зазначити, що відповідне презумптивне положення зафіксоване у пп. 4.4.1 п. 4.4 ст. 4 даного Закону, який іменувався «Конфлікт інтересів». Як принцип податкового законодавства презумпція правомірності рішень платника податків вперше була формалізована в Податковому кодексі України (далі - ПКУ). Варто наголосити на тому, що презумпція правомірності рішень платника податків є самостійним принципом податкового законодавства. Вона закріплена у ст. 4 ПКУ, яка називається «Основні засади податкового законодавства України». Саме в цій статті ПКУ формалізовані всі прямо закріплені принципи податкового законодавства. Зміст відповідного вихідного положення нормативно формалізований у рамках приписів пп. 4.1.4 п. 4.1 ст. 4 ПКУ, де зазначається таке: «Презумпція правомірності рішень платника податку в разі, якщо норма закону чи іншого нормативно-правового акта, виданого на підставі закону, або якщо норми різних законів чи різних нормативно-правових актів припускають неоднозначне (множинне) трактування прав та обов'язків платників податків або контролюючих органів, внаслідок чого є можливість прийняти рішення на користь як платника податків, так і контролюючого органу» [8].

Визначення презумпції правомірності рішень платника податків як принципу податкового законодавства свідчить про основоположність їі значення для регламентації податкових відносин. Так, безумовно, з формально-юридичного погляду норми-принципи не превалюють над звичайними нормами (якщо протилежне прямо не закріплено в законі). Водночас судова практика, за загальним правилом, іде шляхом виокремлення первинності й основоположності вихідних положень права для нормативного регулювання.

Специфічною рисою презумпції правомірності рішень платника податків як нормативного явища є також дуалістичність їі формалізації - вона закріплена в пп. 4.1.4 п. 4.1 ст. 4 ПКУ та в п. 56.21 ст. 56 ПКУ. Важливо зазначити той аспект, що в рамках пп. 4.1.4 п. 4.1 ст. 4 ПКУ закріплений загальний принцип-презумпція, який має системоутворювальне значення. Що ж стосується приписів п. 56.21 ст. 56 ПКУ, то вони мають спеціальне призначення, а саме встановлення відповідного презумптивного правила для адміністративних проваджень із вирішення податкових спорів.

Чи є доцільним таке дублювання змісту даного принципу у спеціальному інституті? Навряд. Закріплення відповідної презумпції як загальносистемного принципу є достатнім, щоб він був поширений на всі інститути податкового права. Навіть більше, адміністративним судам відсут- ність у Кодексі адміністративного судочинства України відповідного принципу зовсім не заважає його застосовувати. У даному разі (щодо дублювання) законодавець радше мав на меті додатково наголосити на основоположності презумпції правомірності рішень платника податків у рамках юрисдикційних проваджень із врегулювання податкових спорів.

У подальшому пропонуємо перейти до судової практики, у якій оформлена судова доктрина презумпції правомірності рішень платника податків. Насамперед варто зазначити, що особливе значення як джерело судової доктрини в Україні має практика Європейського суду з прав людини (далі - ЄСПЛ). Відповідно до приписів ст. 17 Закону України «Про виконання рішень та застосування практики Європейського суду з прав людини», у розгляді справ застосовують практику ЄСПЛ як джерело права [14]. Національні суди повинні керуватися практикою ЄСПЛ у вирішенні спорів, які виникають між платником податків та контролюючими органами. Застосування практики ЄСПЛ останнім часом стало своєрідною ознакою грунтовності правозастосування. Так, безумовно, в окремих випадках національні суди застосовують практику ЄСПЛ суто з формалістичного підходу (без будь-якої об’єктивної необхідності). Проте в цілій низці справ застосування практики ЄСПЛ має осмислений характер.

Потрібно зазначити, що ЄСПЛ дуже рідко у своїй практиці звертається до податково-правової проблематики. Особливо велике значення для розвитку судової доктрини в аспекті врегулювання податкових спорів мало рішення ЄСПЛ у справі «Щокін проти України» від 14 жовтня 2010 р. [15]. Так, саме у відповідному рішенні зафіксовані доктринальні підходи до визначення змісту презумпції правомірності рішень платника податків. Так, у п. 57 даного рішення зазначалося: «<...> Коли національне законодавство припускало неоднозначне або множинне тлумачення прав та обов' язків платників податків, національні органи були зобов'язані застосувати підхід, який був би найбільш сприятливим для платника податків. Однак у справі, що розглядається, органи державної влади віддали перевагу найменш сприятливому тлумаченню національного законодавства, що призвело до накладення на заявника додаткових зобов' язань зі сплати прибуткового податку» [15].

Тобто в рамках відповідного рішення ЄСПЛ навів нормативно закріплені вимоги презумпції правомірності рішень платника податків (у редакції попереднього законодавства) та, фактично, визначив необхідність здійснення контролюючим органом найбільш сприятливого для платника податків тлумачення законодавства. Вимога найбільш сприятливого тлумачення законодавства зумовлюється фактичною нерівністю учасників подат- 
кових відносин (контролюючий орган та платник податків) і публічно-владним характером встановлення нормативних приписів. Тобто ціль відповідного презумптивного положення полягає в забезпеченні підвищених гарантій для невладного суб’єкта податкових відносин.

Влучно та послідовно було застосовано вищезазначене рішення ЄСПЛ у постанові Верховного Суду у складі колегії суддів Касаційного адміністративного суду від 7 вересня 2018 р. (справа № 826/18755/15), де зазначалося таке: «У вказаному рішенні ЄСПЛ, з посиланням на закріплений у законодавстві України принцип in dubio pro tributario, зазначив, що органи державної влади віддали перевагу найменш сприятливому тлумаченню національного законодавства, що призвело до накладення на заявника додаткових зобов'язань зі сплати податку» [10].

У правовій позиції національний суд цікаво провів концептуалізацію відповідного вихідного положення, за посередництвом латинського виразу "in dubio pro tributario", що перекладається як «у разі сумнівів потрібно вирішувати на користь громадянина». Саме собою ввживання латинських виразів у судовій практиці не розширяє змісту доктрини. Застосування латинських формулювань лише створює враження глибинного опрацювання проблематики, видимість етимологічного пошуку джерел формування принципу. Тобто такого роду прийом суб'єкта правозастосування має забезпечити суто зовнішнє враження стосовно комплексності обрамлення формулювань. Водночас ми не можемо назвати застосування в судовій практиці латинських виразів неконструктивним, адже саме такі прийоми зближують судову та наукову доктрину.

Варто зауважити, що доктрина презумпції правомірності рішень платника податків змістово розвинулася також у рамках практики національних судів. У постанові Верховного Суду у складі колегії суддів Касаційного адміністративного суду від 20 листопада 2019 р. (справа № 280/411/19) закріплена така позиція: «Крім того, ураховуючи правило вирішення сумнівів на користь платника податків (тобто принцип in dubio pro tributario), яке покликано забезпечувати реалізацію однієі 3 ознак верховенства права - правової визначеності, саме можливість платника податків чітко розуміти та передбачати правові наслідки вчинюваних дій має фундаментальне значення для правильності його застосування» [12].

3 вищеозначеної позиції вбачається декілька принципових аспектів. По-перше, суди розглядають відповідне презумптивне положення як спеціальне правило, що встановлює вимогу про вирішення всіх сумнівів на користь платника податків. Це дозволяє говорити про своєрідну спробу судів лаконізувати зміст принципу-презумп- ції правомірності рішень платника податків. По-друге, судова доктрина презумпції правомірності рішень платника податків перебуває в нерозривній єдності з вимогами принципу правової визначеності, який є одним із шести інтегративних складників принципу верховенства права. Такого роду підхід пов' язаний із тим, що правова невизначеність зазвичай зумовлюється недосконалістю нормотворчої техніки, яка і призводить до неоднозначного трактування прав і обов'язків учасників суспільних відносин. Саме презумпція правомірності рішень платника податків встановлює спеціальне правило, за посередництвом якого і долається правова невизначеність у податкових відносинах.

Цікавою є також позиція, що була закріплена в постанові Верховного Суду у складі колегії суддів Касаційного адміністративного суду від 21 січня 2020 р. (справа № 820/11382/15). У рамках відповідного судового рішення Судом було здійснено посилання на доповідь Свропейської комісії за демократію через право (Венеціанська комісія) щодо верховенства права від 4 квітня 2011 р. № 512/2009 (далі - Доповідь). У даному рішенні національного суду зазначена важливість принципу правової визначеності й ідеї передбачуваності (очікуваності) суб’єктом суспільних відносин правових наслідків (правовий результат) своєї поведінки. Після аналізу положень відповідного акта «м'якого» права Суд резюмує, що відповідні вимоги втілені і в національному податковому законодавстві, а саме у змісті презумпції правомірності рішень платника податків.

Так, у згаданому вище рішенні зазначається: «<...> Наведені вище догми європейського правозастосування (ідеться про положення Доповіді) були імплементовані в податкове законодавство України. Так, положеннями податкового законодавства закріплено правило вирішення сумнівів на користь платника податків (тобто принцип in dubio pro tributario), яке покликано забезпечувати реалізацію однієї з ознак верховенства права - правової визначеності, а саме: можливість платника податків чітко розуміти та передбачати правові наслідки вчинюваних дій має фундаментальне значення для правильності його застосування» [13]. У даному рішенні було підкреслено зв'язок прогресивних закордонних підходів та їх «рецепції» національним законодавцем. Що ж стосується Суду, то він послідовно розвиває відповідні ідеї та положення в належному прогресивно орієнтованому правовому руслі.

У контексті дослідження судових доктрин презумпції правомірності рішень платника податків потрібно визначити їх співвідношення із судовою доктриною добросовісності платника податків. Презумпція добросовісності платника податків неодноразово була закріплена в судових рішен- 
нях національних судів. Важливо зазначити, що на відміну від презумпції правомірності рішень платника податків, презумпція добросовісності платника податків не має закріплення на нормативному рівні (ані на рівні закону, ані на рівні підзаконного нормативно-правового акта). Потрібно зауважити, що презумпція добросовісності платника податків має більш різнобічну правову природу, аніж вузькоспеціалізована презумпція правомірності рішень платника податків.

Так, у постанові Верховного Суду у складі колегії суддів Касаційного адміністративного суду від 6 червня 2018 р. (справа № 804/7948/16) зазначалося: «При вирішенні податкових спорів презюмується добросовісність платника податку, i, відповідно, обгрунтованість отриманої ним податкової вигоди <...>» [9].

Тобто презумпція добросовісності платника податків прямо пов'язується з доктриною податкових вигод. У даному разі Суд зазначає, що за звичайного алгоритму розвитку податкових відносин презюмується належність виконання платником податків своїх податкових обов'язків, отже, і наявність у такого платника податків права на одержання податкових вигод. Крім цього, презумпція добросовісності платника податків у рамках судової практики мала й інші трактування. Наприклад, у постанові Верховного Суду у складі колегії суддів Касаційного адміністративного суду від 12 листопада 2019 р. (справа № 802/1154/17-а) зазначалося: «Презумпція добросовісності платника податків означає, що подані платником контролюючому органу документи податкової звітності є дійсними, повно та об'єктивно відтворюють господарські операції, що є об'єктом оподаткування та/або фінансові показники яких впливають на податковий обов'язок платника податків, якщо інше не буде доведено контролюючим органом. У площині процесуального регулювання презумпції добросовісності платника податків відповідає обов'язок доведення контролюючим органом правомірності прийнятого рішення в судовому процесі, порушеному за позовом платника податків про скасування рішення як неправомірного <...> [11]. 3 вищезазначеного рішення вбачається, що суд трактує відповідне презумптивне положення як таке, що детермінує належність документів податкової звітності платника податків.

Отже, ми можемо дійти висновку, що презумпція правомірності рішень платника податків, на відміну від презумпції добросовісності платника податків, має більш вузький, техніко-юридичний зміст. Крім цього, саме презумпція правомірності рішень платника податків має первинно нормативну природу, тоді як презумпція добросовісності рішень платника податків має суто судово-доктринальну природу. Водночас важливо, що презумпція правомірності рішень платника податків покликана забезпечити правову визначеність у податковому правозастосуванні тоді, коли закон передбачає неоднозначне трактування прав і обов'язків учасників податкових відносин. Що стосується презумпції добросовісності платника податків, то вона має своїм завданням надати платнику податків певні гарантії, тоді як на контролюючий орган покладає додаткове обтяження щодо доказування. Єдине, що залишається незаперечним, так це похідний від основ адміністративного судочинства характер презумпції добросовісності платника податків, який зумовлюється покладенням тягаря доказування саме на владного суб'єкта (владний суб'єкт повинен довести ті обставини, на які він посилається).

Висновки. Презумпція правомірності рішень платника податків є одним з основоположних принципів податкового законодавства. Окремі аспекти тлумачення відповідного вихідного положення, його концептуалізація відбувалися і в рамках судової практики. Важливо зазначити, що в аспекті формування судової доктрини презумпції правомірності рішень платника податків ідеться не тільки про національну судову практику, але й про практику міжнародних судових інстанцій.

\section{Jimepamypa}

1. Бабаев В.К. Презумпции в советском праве. Горький : Горьковская высшая школа МВД СССР, $1974.124 \mathrm{c}$.

2. Большой юридический словарь / под ред. А.Я. Сухарева, В.Д. Зорькина, В.Е. Крутских. Москва : Игфра, 1997. 790 с.

3. Ведєрніков Ю.А., Папірна А.В. Теорія держави і права : навчальний посібник. Київ : Знання, 2008. 333 с.

4. Грошевой Ю.М. Теоретические проблемы формирования убеждений судьи в советском уголовном судопроизводстве : дис. ... докт. юрид. наук : 12.00.08. Харьков, 1975. 403 с.

5. Іванський А.Й. Роль юридичних презумпцій у регулюванні відносин фінансово-правової відповідальності. Актуальні проблели держави і права. 2008. Вип. 42. С. 221-228. URL: http://www.apdp.in.ua/ v42/40.pdf.

6. Кухарєв О.Є. Застосування правових презумпцій у механізмі правового регулювання спадкових відносин. Вісник Національної академії правових наук України. 2017. № 1 (88). С. 140-151. URL: http://dspace.univd.edu.ua/xmlui/bitstream/ handle/123456789/2142/zastosuvannya_pravovih_ prezumpciy_u_meha.pdf? sequence $=2 \&$ isAllowed $=$ y.

7. Новий тлумачний словник української мови : у 3-х т. / уклад. : В.В. Яременко, О.М. Сліпушко. Київ : Аконіт, 2008. Т. 2. 928 с.

8. Податковий кодекс України, у ред. від 1 липня 2020 p. URL: https://zakon.rada.gov.ua/laws/ show/2755-17\#Text (дата звернення: 08.08.2020).

9. Постанова Верховного Суду у складі колегії суддів Касаційного адміністративного суду від 6 червня 2018 р. (справа № 804/7948/16). URL: http://reyestr.court.gov.ua/Review/74894233 (дата звернення: 11.08.2020).

10. Постанова Верховного Суду у складі колегії суддів Касаційного адміністративного суду від 
7 вересня 2018 р. (справа № 826/18755/15). URL: http://www.reyestr.court.gov.ua/Review/76381181 (дата звернення: 11.08.2020).

11. Постанова Верховного Суду у складі колегії суддів Касаційного адміністративного суду від 12 листопада 2019 р. (справа № 802/1154/17-a). URL: http://reyestr.court.gov.ua/Review/85613226 (дата звернення: 11.08.2020).

12. Постанова Верховного Суду у складі колегії суддів Касаційного адміністративного суду від 20 листопада 2019 р. (справа № 280/411/19). URL: http: / / ww .reyestr.court.gov.ua/Review / 85902311 (дата звернення: 15.08.2020).

13. Постанова Верховного Суду у складі колегії суддів Касаційного адміністративного суду від 21 січня 2020 р. (справа № 820/11382/15). URL: http: / / www.reyestr.court.gov.ua/Review / 87363996 (дата звернення: 15.08.2020).

14. Про виконання рішень та застосування практики Європейського суду з прав людини : Закон України № 3477-IV від 2 грудня 2012 p. URL: https://zakon.rada.gov.ua/laws/show/3477-15\#Text.

15. Рішення ЄСПЛ у справі «Щокін проти України" від 14 жовтня 2010 p. URL: https://zakon.rada.gov.ua/laws/show/974_858\#Text (дата звернення: 20.08.2020).

16. Слюсар А.М. Щодо питання юридичних фікцій у трудовому праві. Право та інноваиї. 2016. № 1 (13). C. 30-34. URL: https://ndipzir.org.ua/wpcontent/uploads/2016/05/Sliusar13.pdf.

\section{Анотація}

Сличок С. М. Презумпція правомірності рішень платника податків у практиці адміністративних судів. - Стаття.

Статтю присвячено детальному аналізу правової природи презумпції правомірності рішень платника податків як одного з вихідних положень податкового законодавства, змістовні аспекти якого розвивалися в межах судової практики. Так, автором було сконцентровано увагу на специфічних рисах презумпціі правомірності рішень платників податків. Відповідні риси встановлюються на основі дослідження, серед іншого, практики Європейського суду з прав людини та Європейської комісії за демократію через право (Венеціанська комісія). Як дослідницьке завдання автором визначено специфіку взаємозв'язків судової доктрини презумпції правомірності рішень платника податків з іншими судовими доктринами, а саме: доктриною ділової мети, доктриною добросовісності платника податків тощо. Проведено розмежування судовоі доктрини презумпції правомірності рішень платника податків від доктрини добросовісності платника податків. Зазначено, що презумпція правомірності рішень покликана забезпечити правову визначеність у податковому правозастосуванні, саме тоді, коли закон передбачає неоднозначне трактування прав і обов'язків учасників податкових відносин. У статті проаналізовано актуальну судову практику, у рамках якої сформовано основні концептуальні вимоги даного презумптивного положення податкового законодавства. Встановлено, що суди розглядають презумпцію правомірності рішень платника податків як спеціальне правило, яке встановлює вимогу, відповідно до якої суб'єкти пра- возастосування повинні трактувати всі нормативно обумовлені сумніви на користь платника податків. Підкреслюється, що саме презумпція правомірності рішень перебуває в нерозривній єдності з вимогами принципу правової визначеності. Сам принцип правової визначеності є елементом принципу верховенства права. Саме дане вихідне положення забезпечує прогнозованість правозастосовної практики. Принцип-презумпція правомірності рішення платника податків $є$ специфічним інструментом (техніко-юридичний прийом), який дозволяє забезпечити реалізацію інтересів платника податків у разі фактичної невизначеності алгоритмів правозастосування.

Ключові слова: презумпція, презумпція правомірності рішень платника податків, судова доктрина, судовапрактика, принципи податковогозаконодавства.

\section{Summary}

Smychok Ye. M. Presumption for legality of taxpayer decisions in the practice of administrative courts. Article.

The article is devoted to a detailed analysis of the legal nature of presumption of legality of taxpayer's decisions one of the initial provisions of tax legislation, the substantive aspects of which developed within the case law. Thus, the author focused on the specific features of the presumption of legality of taxpayer's decisions. Relevant features are established based on research including the case law of the European Court of Human Rights and the European Commission for Democracy through Law (Venice Commission). As a research task, the author paid attention and determined the specifics of the relationship of the judicial doctrine of presumption of legality of taxpayer's decisions with other judicial doctrines, namely: the doctrine of business purpose, the doctrine of good faith of the taxpayer, etc. A distinction is make between the judicial doctrines of the presumption of legality of taxpayer decisions from the doctrine of good faith of the taxpayer. It is note that the presumption of legality of decisions is designed to ensure legal certainty in tax law enforcement precisely in cases, where the law provides for an ambiguous interpretation of the rights and obligations of participants in tax relations. The article analyzes the current case law in which the main conceptual requirements of this presumptive provision of tax legislation are be formed. It is be established that the courts consider the presumption of legality of taxpayer decisions as a special rule, which establishes a requirement which law enforcement entities must interpret all regulatory doubts in favor of the taxpayer. It is emphasize that the presumption of legality of decisions is in inseparable unity with the requirements of the principle of legal certainty. The principle of legal certainty itself is an element of the principle of the rule of law. It is this starting point that ensures the predictability of law enforcement practice. In turn, the principle-presumption of legality of the taxpayer's decision is a specific tool (technical and legal technique) that allows ensuring the realization interests of the taxpayer in case of actual uncertainty of law enforcement algorithms.

Key words: presumption, presumption of legality of taxpayer's decisions, judicial doctrine, judicial practice, principles of tax legislation. 